\title{
Effect of Organic, Inorganic and Nano Fertilizers on Agronomic Traits of Maize
}

\author{
Amany K. El-Habbak, Hassan R. El-Deepah, Mohamed I. Salwau and Nasser Kh. El-Gizawy* \\ Department of Agronomy, Faculty of Agric., Moshtohor, Benha Univ., Egypt \\ *Corresponding author: nasser.elgizawy@ fagr.bu.edu.eg
}

\begin{abstract}
Integrated nutrient management is a judicious application of fertilizer from different sources for sustainable agriculture. Two-year field experiment was conducted at the Agric. Res. and Exp. Center, Fac. of Agric., Moshtohor, Banha Univ., Kalubia Governorate, during the two growing seasons 2016 and 2017, to study the influence of three biogas sludge manure rates $\left(0,3.5,7\right.$ ton/fed), four mineral NP fertilizer i.e. $\left(\mathrm{N}_{0} \mathrm{P}_{0}, \mathrm{~N}_{40} \mathrm{P}_{7.5}\right.$, $\left.\mathrm{N}_{80} \mathrm{P}_{15}, \mathrm{~N}_{120} \mathrm{P}_{22.5} \mathrm{~kg} / \mathrm{fed}\right)$ and three levels of nano micronutrients foliar application $(0,100$ and $200 \mathrm{~g} / \mathrm{fed}) \mathrm{on}$ growth, yield and its component of maize (Zea mays L.). The experiment was laid out in split-split-plot design with three replications. Results of combined analysis of the two seasons showed that increasing biogas rate to 3.5 ton/fed significantly increased grain weight/ear as well as grain and biological yield/fed compared with control. Yield components (ear length, grain weight/ear and 100-grain weight) as well as grain and biological yield (ton/fed) were significantly increased by increasing NP fertilizer levels up to $\mathrm{N}_{80} \mathrm{P}_{15} \mathrm{~kg} / \mathrm{fed}$. Significant effect of nano micronutrients application on No. of ears/plant and 100-grain weight at rate $100 \mathrm{~g} / \mathrm{fed}$ and plant height, grain weight/ear as well as grain and biological yield/fed at rate $200 \mathrm{~g} / \mathrm{fed}$ were detected. Interaction effect between biogas x NP x nano had significant effect on ear length, grain weight/ear as well as grain and biological yield. Treatment 3.5 ton biogas $\times \mathrm{N}_{80} \mathrm{P}_{15} \mathrm{~kg} \times 200 \mathrm{~g}$ nano/fed was the best treatment had $56.02 \%$ more grain yield, in comparison to control with increased soil fertility and saving $33.3 \%$ of mineral fertilizer compared with high fertilizer level.
\end{abstract}

Key words: Organic, Inorganic, Nano Micronutrients, IFM (Integrated Fertilizer Management), Maize.

\section{Introduction}

Maize is considered the most important cereal crop in the world and Egypt came after wheat and rice. It's popularly called "Queen of cereals" due to high genetic yield potentials than any other cereals counterpart (Kannan et al., 2013). It supply nutrients to human and animal as well as used as a source of raw material for the production of oil, protein, starch, food sweeteners and alcoholic beverages as well as fuel source. The highest maize yield production depended on many factors i.e. cultivars and nitrogen fertilization (Hokmalipour and Darbandi, 2011).

Soil fertility improvement is required to stimulate agricultural productivity, improve food security, and raise rural incomes. This can be achieved not only through substantial increases in fertilizer use but also by using different types of fertilizers (Mahmood $\boldsymbol{e t}$ al., 2017).

So, integrated nutrient management is a wise application of fertilizer or manure from different sources to field will maintain the environmental sustainability for generations used without affecting the environmental health (Dadarwal et al., 2009, Wisdom et al., 2012 and Ranjan et al., 2013). Combined application of organic and inorganic nutrient sources improved maize performance than sole application of organic or inorganic fertilizer (Quansah, 2010, Uwah et al., 2011 and Mahmood et al., 2017).

Application of biogas sludge manure significantly increased plant height, leaf area of the topmost ear, stem diameter (El-Hassanin et al., 2002), hastened days to $50 \%$ tasseling (Uwah et al., 2011), enhanced No. of ears/plant, ear characters, 100 grain weight and grain and biological yield/fed (El-Hassanin et al., 2002 and Malav et al., 2015a). While Damiyal et al. (2017) stated that there was no significant difference among cattle manure (CM) means for days to $50 \%$ tasseling in both seasons.

Increasing mineral NP fertilizer significantly increased growth, yield and yield components of maize (Olusegun, 2015, Damiyal et al., 2017 and Reddy et al., 2018). On the other hand, sufficient amount of mineral NP fertilizer decreased No. of days to $50 \%$ tasseling and silking (Fosu-Mensah and Mensah 2016 and Damiyal et al., 2017).

Micronutrients play a significant role in plant growth and metabolic processes associated with photosynthesis, chlorophyll formation and enzyme activities involved in the synthesis of primary and secondary metabolites (Adhikary et. al., 2010).

Several investigators indicated that applied nano micronutrients fertilizer clearly improved growth traits of maize. Plant height and dry matter weight increased due to application of zinc oxide nanoparticle (Adhikari et al., 2015), application of $\mathrm{Cu}$ nano-particles enhanced the growth $(51 \%)$ of maize plant in comparison to control (Adhikari et al., 2016), leaf area, stem diameter, relative water content, and chlorophyll content enhancement due to application of complete nano-micronutrients ( $\mathrm{Fe}, \mathrm{Cu}, \mathrm{Zn}, \mathrm{B}, \mathrm{Mn}$ ) over the control (Janmohammadi et al., 2016 and Subbaiah et al., 2016). Similarly, nano fertilizer 
increased yield and its components of maize (Mosavifeyzabadi et al., 2013, Farnia and Omidi, 2015, Babaeia et al., 2017 and Tiwari 2017).

By considering all these points, the research was conducted to study the effect of organic manure and mineral fertilizers as well as application nano fertilizer on the growth and yield of maize.

\section{Materials and Methods}

Two field experiments were conducted at the Agricultural Research and Experimental Center, Faculty of Agriculture, Moshtohor, Banha University,
Kalubia Governorate, during the two growing seasons 2016 and 2017, to study the influence of organic, mineral and nano fertilizers on some growth, yield and its component of maize (Zea mays L.).

\section{Soil analysis:}

Soil type of the experimental site was clay textured. Soil samples were taken before sowing of crop to depth of $(0-30 \mathrm{~cm})$ for physical and chemical analysis according Rowell (1995). The soil sample analytic report is presented in Table 1 . The preceding crop was wheat in both seasons.

Table 1. Soil physical and chemical analysis (pre-sowing) of experimental farm (Average of the two seasons).

\begin{tabular}{|c|c|c|c|c|c|c|}
\hline $\begin{array}{c}\text { Texture } \\
\text { class }\end{array}$ & $\begin{array}{l}\text { Field water } \\
\text { capacity, \% }\end{array}$ & $\underset{\%}{\text { O.M }}$ & O.C & $\begin{array}{c}\text { pH } \\
(1: 2.5)\end{array}$ & $\begin{array}{c}\mathrm{EC} \\
\left(\mathrm{dSm}^{-1}\right)\end{array}$ & $\mathrm{CaCO}_{3} \%$ \\
\hline Clay & 40.84 & 1.53 & 0.32 & 7.81 & 1.51 & 2.69 \\
\hline \multicolumn{3}{|c|}{ Available mg/kg } & \multirow{2}{*}{\multicolumn{2}{|c|}{$\begin{array}{c}\mathrm{HCO}_{3}^{-} \\
\text {mmolc/L }\end{array}$}} & \multirow{2}{*}{$\begin{array}{c}\mathrm{Na}^{+}, \\
\mathrm{mmolc} / \mathrm{L}\end{array}$} & \multirow{2}{*}{$\begin{array}{c}\mathrm{Ca}^{++}, \\
\mathrm{mmolc} / \mathrm{L}\end{array}$} \\
\hline $\mathbf{N}$ & $\mathbf{P}$ & $\mathbf{K}$ & & & & \\
\hline 19.56 & 7.98 & 113.89 & & & 3.32 & 3.68 \\
\hline \multicolumn{5}{|c|}{ Available micronutrients mg/kg } & & \\
\hline Mn & $\mathbf{F e}$ & Zn & & & & \\
\hline 8.5 & 27.0 & 2.8 & & & & \\
\hline
\end{tabular}

\section{Treatments:}

Thirty six treatments which were the combinations of three levels of biogas sludge manure $(0,3.5,7.0$ ton/fed), four level of NP mineral fertilizer $\left(\mathrm{N}_{0} \mathrm{P}_{0}\right.$, $\left.\mathrm{N}_{40} \mathrm{P}_{7.5}, \mathrm{~N}_{80} \mathrm{P}_{15}, \mathrm{~N}_{120} \mathrm{P}_{22.5} \mathrm{~kg} / \mathrm{fed}\right)$ and three levels of mixed Nano-micronutrients fertilizer $(0,100,200$ $\mathrm{g} / \mathrm{fed})$.
Biogas sludge manure obtained from anaerobic digestion of organic matter was collected from the training center for biogas and recycling the agricultural residues (TCRAR), Moshtohor, Kalubia Governorate, Soils, Water and Environment Res. Inst., A.R.C. Giza, Egypt. The Biogas sludge manure was air-dried and was added prior to final plowing. Chemical analysis is presented in (Table 2).

Table 2. Chemical analysis of the Biogas sludge manure (BSM) (Average of the two seasons).

\begin{tabular}{lc}
\hline Properties & Value \\
\hline $\mathrm{pH}(1: 10 \mathrm{BSM}$-water) & 7.50 \\
EC dS m ${ }^{-1}(1: 10 \mathrm{BSM}$-water) & 2.52 \\
Organic matter (\%) & 40.8 \\
\hline Macronutrients & \\
Total N (\%) & 1.71 \\
Total P (\%) & 0.72 \\
Total K (\%) & 0.78 \\
\hline Micronutrients (ppm) & \\
$\mathrm{Zn}$ & 42 \\
$\mathrm{Fe}$ & 315 \\
$\mathrm{Mn}$ & 44 \\
$\mathrm{Cu}$ & 2 \\
\hline
\end{tabular}

Urea $\mathrm{CO}\left(\mathrm{NH}_{2}\right)_{2}(46.5 \% \mathrm{~N})$ was used as the nitrogen source in both seasons which applied to the soil in two equal doses before $1^{\text {st }}$ and $2^{\text {nd }}$ irrigation, while calcium super phosphate $\left(15.5 \% \quad \mathrm{P}_{2} \mathrm{O}_{5}\right)$ was used as the phosphor source in both season was applied to the soil before planting irrigation.

Magrow NanoMix ${ }^{\circledR}$ was used as Nanomicronutrients fertilizer obtained from the Ministry of Agric. and Land Rec., Egypt, under registration No. : 5443. It contained $\mathrm{Fe}(6 \%), \mathrm{Mn}(5 \%), \mathrm{Cu}(1 \%), \mathrm{B}$
(2\%), Mo (0.1\%) and Citric acid (4\%). Synthesized nanoparticles were characterized morphologically by transmission electron microscopy and the average of its particles was $63.81 \mathrm{~nm}$. Application of Nanomicronutrients was sprayed after 45 days. Spray solution was $600 \mathrm{~L} / \mathrm{fed}$.

\section{Experimental design:}

The experiment was laid out in split-split-plot design with three replications. The main plots were 
devoted for biogas sludge manure and sub plots were occupied by mineral NP fertilizer levels. Whereas, three foliar application of Nano-microelements fertilizer were randomly distributed in the sub- subplot. The area of sub-sub plot was $10.5 \mathrm{~m}^{2}$ contains 5 ridges ( $3 \mathrm{~m}$ long $\mathrm{x} 0.7 \mathrm{~m}$ width).

Yellow maize hybrid (SC 168) was produced by Field Crops Research Institute of the Agricultural Research Center, Giza, Egypt. It was planted on $13^{\text {th }}$ June and $14^{\text {th }}$ June in 2016 and 2017 seasons, respectively and harvested on $3^{\text {th }}$ October and $5^{\text {th }}$ October in 2016 and 2017 seasons, respectively. Maize seeds were planted in hills at $25 \mathrm{~cm}$ apart and then plants were thinned to one plant/hill (24000 plant/fed) before the first irrigation. Culture practices of growing maize followed as recommended for the region.

\section{Collected data:}

Number of days from planting to $50 \%$ tasseling and silking, plant height at maturity $(\mathrm{cm})$, ear position (\%) was estimated by dividing (ear height $\times 100)$ by plant height, No. of ears per plant, ear length $(\mathrm{cm})$, ear diameter $(\mathrm{mm})$, grain weight/ear $(\mathrm{g}), 100$-grains weight $(\mathrm{g})$, grain and biological yields (ton/fed).

\section{Statistical analysis:}

Analysis of variance was performed using MSTATC statistical software package (Freed, 1991). Before conducting a combined analysis over years, error variances were tested for homogeneity by using Bartlett test and mean combined comparisons were performed using the least significant differences (LSD) test with a significance level of 5\% (Gomez and Gomez, 1984).

\section{Results and Discussion}

\section{Effect of organic manure (biogas):}

Results presented in Table 3 show that application of different rates of biogas sludge manure had no significant effects $(P<0.05)$ on growth and yield attributes of maize, except ear grain weight as well as grain and biological yield, in the combined analysis of both seasons. Application the highest rate of biogas sludge manure 7 ton/fed was accompanied by decreased in number of days to $50 \%$ tasseling and silking, increased plant height and number of ears/plant, ear length and diameter, 100 grain weight, ear grain weight as well as grain and biological yields/fed. On the other hand, ear position behaved the reverse. Increasing biogas up to 7 ton/fed significantly increased $(P<0.05)$ ear grain weight, grain and biological yields /fed by $4.49 \%, 15.70$ and $5.70 \%$, respectively, as compared to control (no biogas) in combined analysis of the two seasons. It seemed that applied biogas sludge manure provided a constant supply of macro and micronutrients during life cycle of maize which enhanced photosynthesis and protein synthesis in the leaves and this in turn to growth and yield (Malav et al., 2015b and Nyang'au et al., 2016). These results are in agreement with those obtained with (El-Hassanin et al., 2002 and Malav et al., 2015a). It is worth to noting that, Biogas sludge manure due the slow release of its nutrient for uptake by maize plants probably no had significant effect on some traits of maize. These results are in accordance with Damiyal et al. (2017) stated that there was no significant difference among cattle manure (CM) means for days to $50 \%$ tasseling in both seasons.

\section{Effect of mineral NP fertilizer:}

Data listed in Table 3 indicate that mineral NP fertilizer had no significant effect $(P<0.05)$ on No. of days to $50 \%$ tasseling and silking, ear position, No. of ears/plant and ear diameter in analysis pooled. However, increasing NP rate up to $\mathrm{N}_{80} \mathrm{P}_{15} \mathrm{~kg} / \mathrm{fed}$ hastened days to $50 \%$ tasseling (58.87 days) and silking (60.82 days) as compared to $\mathrm{N}_{0} \mathrm{P}_{0}$ (control) were 59.13 and 61.37 days, respectively. Ear grain weight as well as grain and biological yields/fed significantly increased $(P<0.05)$ by increasing NP fertilizer levels up to $\mathrm{N}_{80} \mathrm{P}_{15} \mathrm{~kg} / \mathrm{fed}$ compared with lower fertilizer levels and control. While plant height, ear length and 100 grain weight significantly increased up to $\mathrm{N}_{120} \mathrm{P}_{22.5} \mathrm{~kg} / \mathrm{fed}$. These results clarified that increasing mineral NP fertilizer significantly increased growth, yield and yield components of maize (Olusegun 2015, Damiyal $\boldsymbol{e t}$ al., 2017 and Reddy et al., 2018).

Maximum grain yield (5.89 ton/fed) was achieved by the application of $\mathrm{N}_{80} \mathrm{P}_{15} \mathrm{~kg} / \mathrm{fed}$ compared to the other treatments. This treatment produced also the highest No. of ears/plant (1.21), ear diameter (48.19 $\mathrm{mm})$ and ear grain weight (192.16 g), this indicated strongly correlated between yield and its attributes. The application of $\mathrm{N}_{40} \mathrm{P}_{7.5}, \mathrm{~N}_{80} \mathrm{P}_{15}$ and $\mathrm{N}_{120} \mathrm{P}_{22.5} \mathrm{~kg} / \mathrm{fed}$ increased the grain yield over the control treatment by $14.14,20.70$ and $15.16 \%$, and biological yield by $10.60,15.42$ and $12.04 \%$ respectively. It seemed that, yield and its attributes of maize were significantly increased with application of $\mathrm{N}_{80} \mathrm{P}_{15}$ /fed than high $\mathrm{N}_{120} \mathrm{P}_{22.5}$ /fed fertilizer rate. This might be due to the well utilization of NP fertilizer in metabolism under $\mathrm{N}_{80} \mathrm{P}_{15} \mathrm{~kg} / \mathrm{fed}$ over than high rate of mineral $\mathrm{NP}$ fertilizer. The application of $\mathrm{N}$ at $250 \mathrm{~kg} \mathrm{ha}^{-1}$ produced highest grain yield $\left(8.27 \mathrm{t} \mathrm{ha}^{-1}\right)$ contrary grain yield decreased with increased application of $\mathrm{N}$ up to 300 $\mathrm{kg} \mathrm{ha}^{-1}$ (Hammad et al.,2011). Similar results were reported by Oktem et al. (2010) and Bavec et al. (2013). 
Table 3. Effect of organic, inorganic and nano fertilizer levels on agronomic traits of maize in the combined analysis of both seasons.

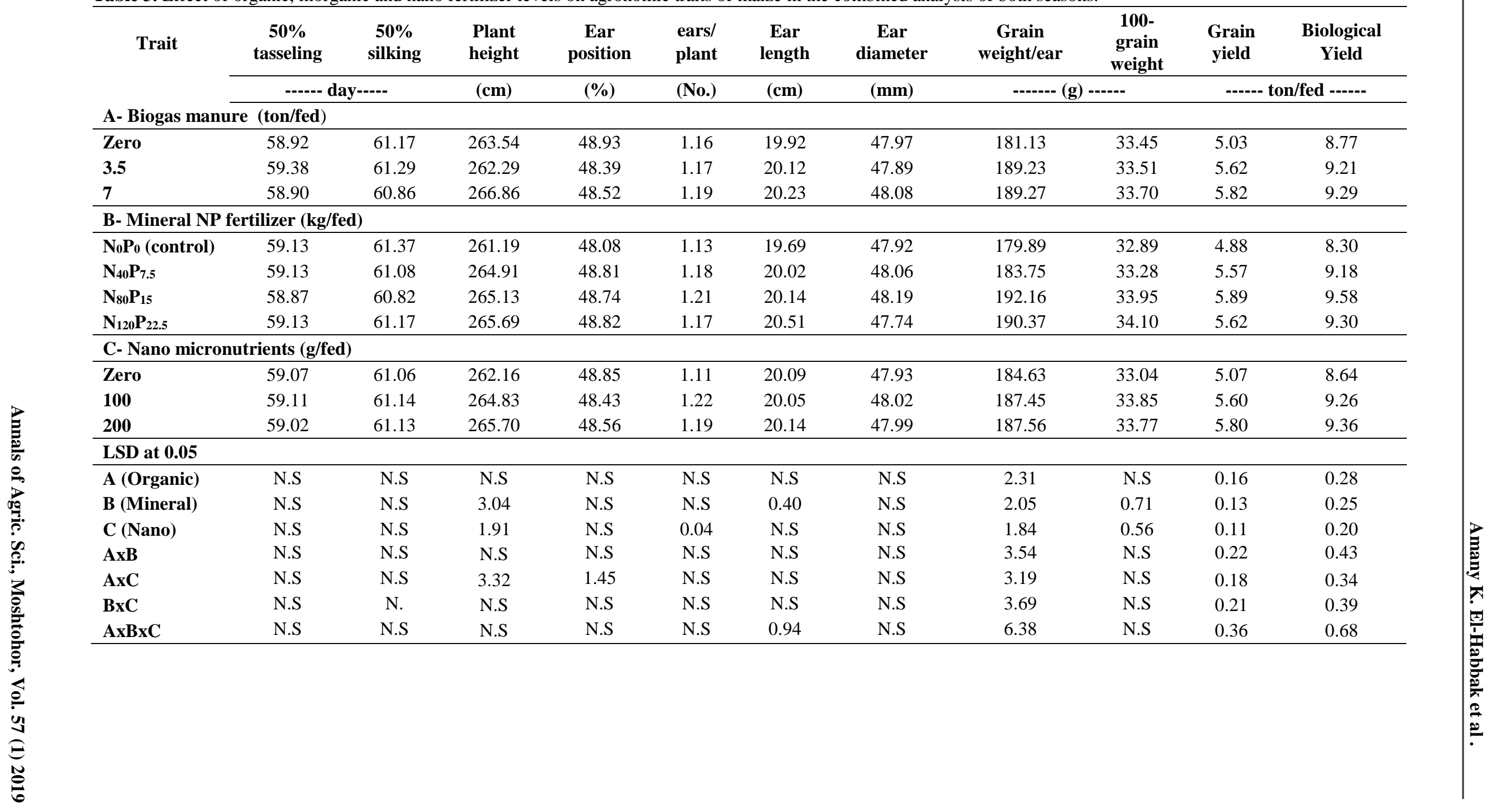




\section{III.Effect of nano fertilizer:}

Application of different rates of nano micronutrients fertilizer showed non-significant effect on days to $50 \%$ tasseling and silking of maize (Table $3)$. However, application nano fertilizer rate at 200 $\mathrm{g} /$ fed reduced days to $50 \%$ tasseling (59.02 days). Similarly ear position, ear length and ear diameter were not differed significantly by application of nano micronutrients fertilizer. In the contrary, foliar application of nano fertilizer significantly affected $(P<0.05)$ on plant height, number of ears/plant, ear grain weight, 100 grain weight as well as grain and biological yields/fed. The highest values of number of ears/plant and 100 grain weight were recorded with nano fertilizer at $100 \mathrm{~g}$ nano/fed, but the maximum plant height, ear grain weight as well as grain and biological yields were detected at $200 \mathrm{~g}$ nano/fed. While the lowest values of these traits were recorded with control (untreated). The increase in grain yield due to foliar application of nano micronutrients at 100 and $200 \mathrm{~g} /$ fed were 10.45 and $14.40 \%$ compared to control. This indicated that applied nano micronutrients fertilizer clearly increased maize grain yield and its components (Mosavifeyzabadi et al., 2013, Farnia and Omidi, 2015, Babaeia et al., 2017 and Tiwari 2017).

\section{Interaction effect:}

\section{IV-1 Interaction between biogas sludge manure and mineral fertilizer (AB):}

It is evident from the results in Table 4 that the effect of this interaction on ear grain weight, grain and biological yields/fed was significant $(P<0.05)$ in the combined analysis of two seasons. The maximum ear grain weight and biological yield was produced by supplementary application of $\mathrm{N}_{120} \mathrm{P}_{22.5} \quad \mathrm{~kg} / \mathrm{fed}$ fertilizer with 7 ton/fed biogas sludge manure, whereas applied $\mathrm{N}_{80} \mathrm{P}_{15} \mathrm{~kg} / \mathrm{fed}$ with the same rat of biogas sludge manure was achieved the highest grain yield/fed (6.22 ton/fed). The lowest values in these traits were obtained from no application of organic and mineral fertilizer. These results clearly indicated that combined application of organic and inorganic nutrient sources improved maize performance than sole application of organic or inorganic fertilizer. These results here are harmony with those obtained by Quansah (2010) Uwah et al., (2011), Endris and Dawid (2015) and Mahmood et al. (2017). Malav et al.(2015a) indicating that $50 \%$ biogas slurry (BGS) along with $50 \%$ chemical fertilizer gave $20 \%$ more yield in terms of cob as well as biomass.

Table 4. Interaction effect of organic, inorganic fertilizer levels on agronomic traits of maize in the combined analysis of both seasons.

\begin{tabular}{|c|c|c|c|c|}
\hline \multirow[t]{2}{*}{$\begin{array}{c}\text { Biogas } \\
\text { Ton/fed } \\
\end{array}$} & \multirow{2}{*}{$\begin{array}{c}\begin{array}{c}\text { Mineral } \\
\text { Kg/fed }\end{array} \\
\mathrm{N}_{0} \mathrm{P}_{0}\end{array}$} & \multirow{2}{*}{$\begin{array}{c}\begin{array}{c}\text { Grain weight/ear } \\
\text { (g) }\end{array} \\
171.96\end{array}$} & \multicolumn{2}{|c|}{$\begin{array}{l}\text { Grain yield Biological yield } \\
-\end{array}$} \\
\hline & & & 4.38 & 7.56 \\
\hline \multirow[t]{4}{*}{ Zero } & $\mathbf{N}_{40} \mathbf{P}_{7.5}$ & 180.34 & 5.01 & 9.02 \\
\hline & $\mathbf{N}_{80} P_{15}$ & 189.21 & 5.53 & 9.63 \\
\hline & $\mathbf{N}_{120} P_{22.5}$ & 183.02 & 5.20 & 8.83 \\
\hline & $\mathbf{N}_{0} \mathbf{P}_{0}$ & 182.08 & 5.15 & 8.87 \\
\hline \multirow[t]{4}{*}{3.5} & $\mathbf{N}_{40} \mathbf{P}_{7.5}$ & 190.78 & 5.80 & 9.36 \\
\hline & $\mathbf{N}_{80} \mathbf{P}_{15}$ & 193.99 & 5.92 & 9.42 \\
\hline & $\mathbf{N}_{120} P_{22.5}$ & 190.25 & 5.59 & 9.19 \\
\hline & $\mathbf{N}_{0} \mathbf{P}_{0}$ & 185.65 & 5.12 & 8.47 \\
\hline \multirow[t]{3}{*}{7} & $\mathbf{N}_{40} \mathbf{P}_{7.5}$ & 180.14 & 5.91 & 9.13 \\
\hline & $\mathbf{N}_{80} \mathbf{P}_{15}$ & 193.27 & 6.22 & 9.67 \\
\hline & $\mathbf{N}_{120} \mathbf{P}_{22.5}$ & 197.85 & 6.08 & 9.86 \\
\hline \multicolumn{2}{|c|}{ LSD 0.05 (AB) } & 3.54 & 0.22 & 0.43 \\
\hline
\end{tabular}

\section{IV-2 Interaction between biogas sludge manure and nano fertilizer (AC):}

Interaction between biogas sludge manure and nano fertilizer had significant effect $(P<0.05)$ on ear position, grain weight/ear, grain and biological yields/fed as shown in Table 5. The best plant height (267.33) was produced by applied 7 ton biogas +200 $\mathrm{g}$ nano/fed whereas, the lowest one resulted from zero biogas + zero nano. But the best ear position (47.50\%) was produced by applied 3.5ton biogas $+100 \mathrm{~g}$ nano/fed, whereas the highest ear position was recorded by control. Maize plants that received 7 ton/fed biogas achieved the highest values of grain weight/ear and grain yield/fed when nano fertilizer applied at zero and $200 \mathrm{~g} / \mathrm{fed}$, respectively, while the lowest values of these traits were produced by zero biogas and zero nano fertilizer. These results may be due to high rate of biogas which is rich in nutrients and can supply all major macronutrients $(\mathrm{N}, \mathrm{P}, \mathrm{K}, \mathrm{Ca}, \mathrm{Mg}$, $\mathrm{S})$ essential for plant development, as well as micronutrients (Alam, 2006 and Nyang'au et al., 2016). However, the maximum biological yield ( 9.41 ton/fed) was obtained with 3.5 ton biogas and 100 or $200 \mathrm{~g} / \mathrm{fed}$ nano fertilize, while the lowest values was achieved with control. This result indicated vital role of organic and nano micronutrients fertilizer in increased grain and biological yields/fed. These results are in agreement with those obtained by Babaeia et al. (2017) and Tiwari (2017). 
Table 5. Interaction effect of organic and nano fertilizer levels on agronomic traits of maize in the combined analysis of both seasons.

\begin{tabular}{|c|c|c|c|c|c|c|}
\hline $\begin{array}{l}\text { Biogas } \\
\text { ton/fed }\end{array}$ & $\begin{array}{l}\text { Nano } \\
\text { g/fed }\end{array}$ & $\begin{array}{c}\text { Plant } \\
\text { height } \\
(\mathrm{cm})\end{array}$ & $\begin{array}{c}\text { Ear } \\
\text { position } \\
\% \\
\end{array}$ & $\begin{array}{c}\text { Grain } \\
\text { weight/ear } \\
\text { (g) }\end{array}$ & \multicolumn{2}{|c|}{ 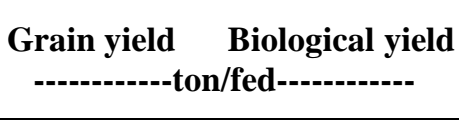 } \\
\hline \multirow{3}{*}{ Zero } & Zero & 259.65 & 49.73 & 175.57 & 4.53 & 8.06 \\
\hline & 100 & 266.87 & 48.28 & 185.25 & 5.19 & 8.96 \\
\hline & 200 & 264.09 & 48.67 & 182.58 & 5.38 & 9.26 \\
\hline \multirow{3}{*}{3.5} & Zero & 260.00 & 48.80 & 183.84 & 5.35 & 8.80 \\
\hline & 100 & 261.19 & 47.50 & 191.69 & 5.57 & 9.41 \\
\hline & 200 & 265.69 & 48.87 & 192.30 & 5.92 & 9.41 \\
\hline \multirow{3}{*}{7} & Zero & 266.83 & 48.02 & 194.47 & 5.38 & 9.06 \\
\hline & 100 & 266.43 & 49.50 & 185.42 & 6.04 & 9.37 \\
\hline & 200 & 267.33 & 48.05 & 187.80 & 6.08 & 9.40 \\
\hline \multicolumn{2}{|c|}{ LSD 0.05 (AC) } & 3.32 & 1.45 & 3.19 & 0.18 & 0.34 \\
\hline
\end{tabular}

\section{IV-3 Interaction between NP mineral fertilizer} and nano fertilizer (BC):

Data illustrated in Table 6 clearly indicated that mineral NP and nano fertilizer had significantly affected $(P<0.05)$ on grain weight/ear, grain and biological yields/fed. The highest grain weight/ear as well as grain and biological yields/fed were obtained by applied $\mathrm{N}_{80} \mathrm{P}_{15}$ and foliar application of nano fertilizer at 100 or $200 \mathrm{~g} / \mathrm{fed}$. It is worth to noting that, differences between two rates of nano fertilizer failed to reach level of significance with respect to grain and biological yields. While the lowest values of these traits were recorded with $\mathrm{N}_{0} \mathrm{P}_{0}$ and zero nano fertilizer. These results may be attributed to the improving role of NP and nano fertilizer in encouraging biosynthesis, cell division and cell enlargement as well as its effect in activating enzymes and increased yield and its components. Similar results were reported by Oktem et al. (2010), Bavec et al. (2013), Farnia and Omidi (2015), Babaeia et al. (2017) and Tiwari (2017).

Table 6. Interaction effect of inorganic and nano fertilizer levels on agronomic traits of maize in the combined analysis of both seasons.

\begin{tabular}{|c|c|c|c|c|}
\hline & & Grain weight/ear & Grain yield & Biological yield \\
\hline $\begin{array}{c}\text { Mineral } \\
\text { Kg/fed }\end{array}$ & $\overline{N a n o(g / f e d)}$ & (g) & --1------ tol & - \\
\hline \multirow{3}{*}{$\begin{array}{c}\mathbf{N}_{0} \mathbf{P}_{0} \\
\text { Control }\end{array}$} & Zero & 178.60 & 4.59 & 7.71 \\
\hline & 100 & 176.31 & 4.99 & 8.59 \\
\hline & 200 & 184.77 & 5.06 & 8.60 \\
\hline \multirow{3}{*}{$\mathbf{N}_{40} \mathbf{P}_{7.5}$} & Zero & 182.16 & 4.97 & 8.28 \\
\hline & 100 & 185.80 & 5.69 & 9.48 \\
\hline & 200 & 183.30 & 6.06 & 9.76 \\
\hline \multirow{3}{*}{$\mathbf{N}_{80} \mathbf{P}_{15}$} & Zero & 190.67 & 5.44 & 9.38 \\
\hline & 100 & 195.75 & 6.10 & 9.82 \\
\hline & 200 & 190.06 & 6.12 & 9.54 \\
\hline \multirow{3}{*}{$\mathbf{N}_{120} \mathbf{P}_{22.5}$} & Zero & 187.07 & 5.33 & 9.20 \\
\hline & 100 & 191.95 & 5.62 & 9.13 \\
\hline & 200 & 192.10 & 5.93 & 9.55 \\
\hline \multicolumn{2}{|c|}{ LSD 0.05 (BC) } & 3.69 & 0.36 & 0.68 \\
\hline
\end{tabular}

IV-4 Interaction between three factors (ABC):

Ear length, grain weight/ear as well as grain and biological yields/fed were significantly affected $(P<0.05)$ by interaction between three different sources of fertilizers (Table 7). The highest values of ear length $(21.13 \mathrm{~cm})$ and grain weight/ear $(201.14 \mathrm{~g})$ were obtained by 7 ton biogas combined and $\mathrm{N}_{120} \mathrm{P}_{22.5}$ without nano fertilizers applied. While combined 3.5 ton biogas and $\mathrm{N}_{80} \mathrm{P}_{15}$ with 100 or $200 \mathrm{~g} / \mathrm{fed}$ nano micronutrients achieved maximum grain and biological yields/fed. No fertilizer of biogas, mineral and nano fertilizer recorded the lowest values of these traits in the combined analysis of both seasons. This indicated integrated different sources of fertilizer enhancement maize grain yield and can reduce the use of chemical fertilizers (about $33.3 \%$ NP per fed). 
Table 7. Interaction effect of organic, inorganic and nano fertilizer levels on agronomic traits of maize in the combined analysis of both seasons.

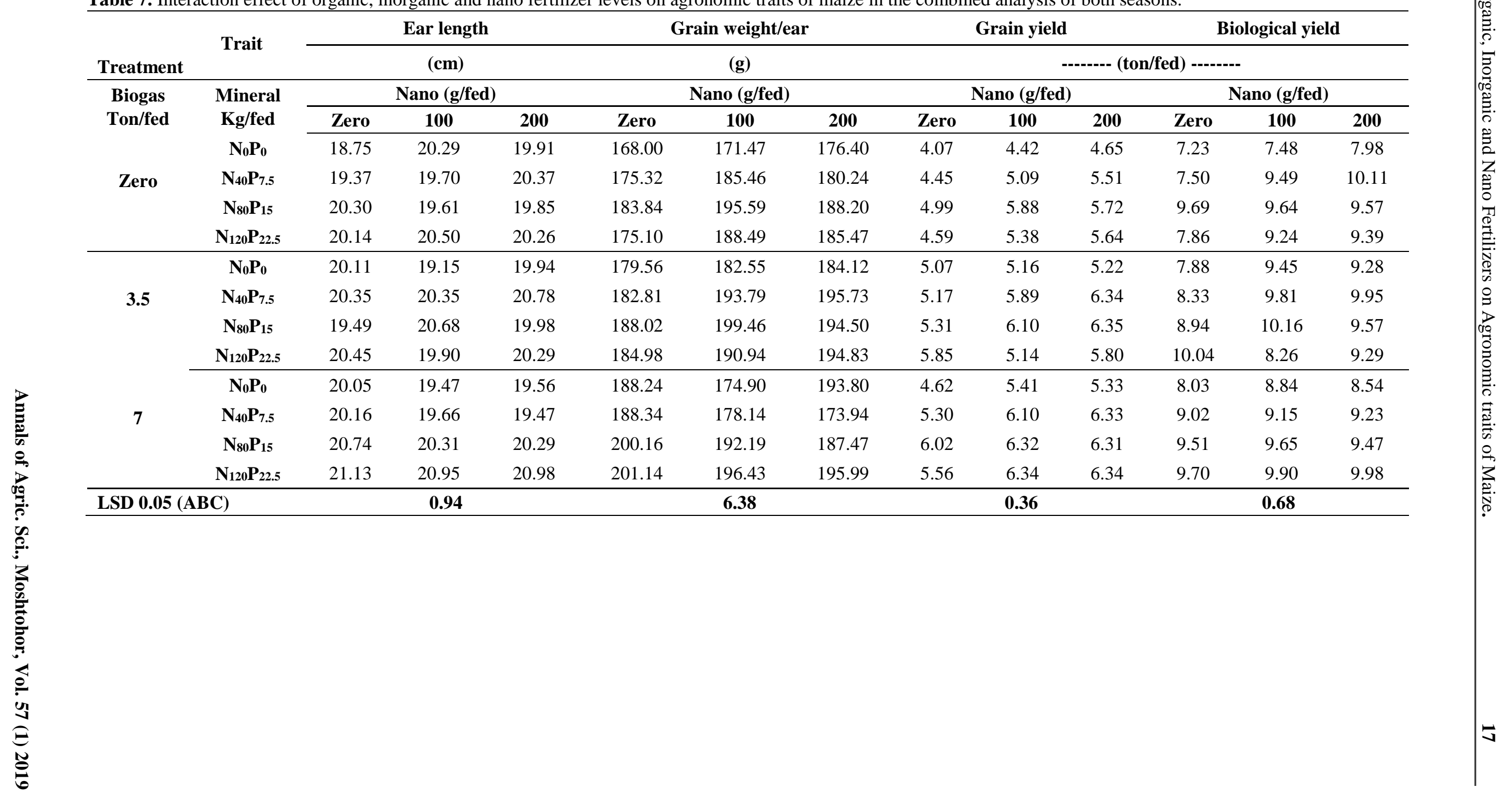




\section{Conclusion}

It can be concluded that, 3.5 ton biogas sludge manure improved performance of maize and significantly increased grain yield/fed. The maximum grain yield and biological yield were obtained by $\mathrm{N}_{80} \mathrm{P}_{15} \mathrm{~kg} / \mathrm{fed}$ applied. This application saved about $33.33 \%$ of mineral NP fertilizer which reduced environmental pollution and cost of fertilizer. Nano micronutrients fertilizer stimulated maize grain yield. Therefore, combined application of organic, inorganic and nano fertilizers at moderate (3.5 ton biogas plus $\mathrm{N}_{80} \mathrm{P}_{15}$ and foliar application of nano fertilizer at $200 \mathrm{~g} / \mathrm{fed}$ ) may be recommended under the condition of this study.

\section{References}

Adhikari, T.; S. Kundu; A. K. Biswas; J. C. Tarafdar and A. Subba Rao (2015). Characterization of zinc oxide nano particles and their effect on growth of maize (Zea mays l.) Plant. J. of Plant Nutr., 38:1505-1515.

Adhikari, T.; D.Sarkar; H. Mashayekhi and B. Xing (2016). Growth and enzymatic activity of maize (Zea mays L.) plant: Solution culture test for copper dioxide nano particles. J. of Plant Nutr., 39(1): 99-115.

Adhikary, B.H.; J. Shrestha and B.R. Baral (2010). Effects of micronutrients on growth and productivity of maize in acidic soil. Inter. Res. J. Appl. and Basic Sci., 1(1): 8-15.

Alam, S. (2006). Production of organic manure in Bangladesh, Bangladesh Livestock Research Institute's Report, Savar, Dhaka, Bangladesh.

Babaeia, Kh.; R. S. Sharifia; A. Pirzadb and R.Khalilzadeh (2017). Effects of bio fertilizer and nano $\mathrm{Zn}-\mathrm{Fe}$ oxide on physiological traits, antioxidant enzymes activity and yield of wheat (Triticum aestivum L.) under salinity stress. J. of Plant Inter., 12 (1):381-389.

Bavec, F.; M. Bavec and M. Fekonja (2013). Organic and mineral nitrogen fertilizers in sweet maize (Zea mays L. saccharata Sturt.) production under temperate climate. Zemdirbyste-Agric., 100 (3): 243-250.

Dadarwal, R. S.; N.K. Jain and D.Singh (2009). Integrated nutrient management in baby corn ( $\mathrm{Zea}$ mays L.). Indian J. of Agric. sci., 79 (12): 1023-5.

Damiyal, D.M; W. Manggoel; S. Ali; D.Y. Dalokom and I.M. Mashat (2017). Effect of cattle manure and inorganic fertilizer on the growth and yield of hybrid maize (Zea mays L.). World Res. J. Agric. Sci., 4(1): 102-110.

El-Hassanin, A.S.; M.I. Mahmoud; Samia, M.M. Amer and Hoda, K.A. El-Mekser (2002). Response of maize to mineral, organic and biofertilizers under calcareous soil conditions. Egypt. J. Appl. Sci.; 17(1): 91-104.

Endris, S. and J. Dawid (2015). Yield response of maize to integrated soil fertility management on acidic nitosol of southwestern Ethiopia. J. of Agron., 14: 152-157.

Farnia, A.and M. M. Omidi (2015). Effect of Nano-Zinc Chelate and Nano-Biofertilizer on Yield and Yield Components of Maize (Zea mays L.), Under Water Stress Condition. Indian J. of Natural Sci., 5 (29): 4614-4624.

Freed R. D. (1991). MSTATC Microcomputer Statistical Program. Michigan State University, East Lansing, Michigan, USA.

Fosu-Mensah, B.Y. and M. Mensah (2016). The effect of phosphorus and nitrogen fertilizers on grain yield, nutrient uptake and use efficiency of two maize (Zea mays L.) varieties under rain fed condition on Haplic Lixisol in the forest- ${ }^{-}$savannah transition zone of Ghana. Environ Syst Res., 5:22

Gomez, K.A. and Gomez, A. A. (1984): Statiscal procedures for agricultural research. $2^{\text {nd }}$, (ed.). Jon Wiley and Sons, NY U.S.A.

Hammad, H. M.; A. Ahmad; A. Wajid and J. Akhter (2011). Maize response to time and rate of nitrogen application. Pak. J. Bot., 43(4): 19351942.

Hokmalipour, S. and M. H. Darbandi (2011). Effects of nitrogen fertilizer on chlorophyll content and other leaf indicate in three cultivars of maize (Zea mays L.). World Appl. Sci. J., 15 (12): 1780-1785.

Janmohammadi, M.; A. Navid ; A. E. Segherloo and N. Sabaghnia (2016). Impact of nanochelated micronutrients and biological fertilizers on growth performance and grain yield of maize under deficit irrigation condition. Biologija, 62(2):134-147.

Kannan, R.L., Dhivya, M., Abinaya, D., Krishna, R.L., and kumar, S.K. (2013). Effect of Integrated Nutrient Management on Soil Fertility and Productivity in Maize. Bull. of Environ., Phamac. and Life Sci., 2 (8): 61-67.

Mahmood, F.; I. Khan; U. Ashraf; T. Shahzad; S. Hussain1;M. Shahid; M. Abid and S. Ullah (2017). Effects of organic and inorganic manures on maize and their residual impact on soil physicochemical properties. J. of Soil Sci. and Plant Nutr., 17 (1): 22-32.

Malav, L. C.; S. A. Khan and N. Gupta (2015a). Impacts of Biogas Slurry Application on Soil Environment, Yield and Nutritional Quality of Baby Corn. Inter. J. of plant Res., 28 (2): 194-202.

Malav, L. C.; S. A. Khan; N. Gupta; S. Kumar; R. Bhattacharyya and M. K. Malav (2015b). Effect of Biogas Slurry and Urea on Soil Health. J. of Agric. Physics, 15 (1): 55-62.

Mosavifeyzabadi, S.H.; F. Vazin and M. Hassanzadehdelouei (2013). Effects of nitrogen and zinc on yield of corn in drought stress. Cercetări Agron. in Moldova, 46 (3):29-38.

Nyang'au, J.; G. Erastus; N. Christopher and A. Steve (2016). Evaluation of biogas slurry as an 
alternative organic fertilizer a case study in Kenya. Inter. J. of Ext. Res., 9:10-14.

Oktem, A.; A.G. Oktem and H. Y. Emeklier (2010). Effect of nitrogen on yield and some quality parameters of sweet corn. Communications in Soil Sci. and Plant Analysis, 41: 832-847.

Olusegun O. S.(2015). Nitrogen (N) and phosphorus (P) fertilizer application on maize (Zea mays L.) growth and yield at Ado-Ekiti, SouthWest,Nigeria. AJEA. 6(1): 22-29.

Quansah, G. W. (2010). Effect of organic and inorganic fertilizers and their combinations on the growth and yield of maize in the semi-deciduous forest zone of Ghana. M.Sc. thesis, Fac. of Agric., Kwame Nkrumah Univ., Ghana.

Ranjan, J.K.; N.Ahmed; B.Das; P. Ranjan and B.K. Mishra (2013). Green Technology for Production of Baby Corn (Zea mays L.) Under North-West Himalayan Conditions. Inter. J. of Chem Tech Res., 5 (2): 880-885.

Reddy, U.V. B.; G. P. Reddy; M. S. Reddy and P.Kavitha (2018). Effect of different nitrogen and phosphorus levels on growth and yield of maize during kharif season.
Rowell; D.L. (1995). Soil science methods and applications. Library of Congress Cataloging Publication Data. New York. NY 10158. USA.

Subbaiah, L.V.; T.N. Prasad; T.G. Krishna; P. Sudhakar; B.R. Reddy and T.Pradeep (2016). Novel effects of nanoparticulate delivery of zinc on Growth, productivity, and zinc biofortification in maize (Zea mays L.). J Agric. Food Chem., 64(19):3778-3788.

Tiwari, P.K. (2017). Effect of zinc oxide nanoparticles on germination, growth and yield of maize. Ph.D. Thesis, B. A. College of Agric. ANAND Agric. Univ.

Uwah, D.F.; A.E. Eneji and U.J. Eshiet (2011). Organic and mineral fertilizers effects on the performance of sweet maize (Zea mays $L$. Saccharata strut.) In south Eastern rainforest zone of Nigeria Inter. J. of Agric. Sci., 3 (1):54-61.

Wisdom, S. G.O; R.W. Ndana and Y. Abdulrahim (2012). The Comparative study of the effect of organic manure cow dung and inorganic fertilizer N.P.K on the growth rate of maize (Zea mays L). Int. Res. J. Agric. Sci. Soil Sci. 2(12):516-519. 


\section{تأثير السماد العضوى وغير العضوى والنانوعلى الصفات المحصولية للارة الشامية \\ أمانى كامل الهجاق, حسن رمضان الديبة، محمد إسماعيل سلوع، ناصر خميس الجيزاوى \\ قسم المحاصيل - كلية الزراعة بمثتهر - جامعة بنها - مصر.}

تعتبرالأدارة المتكاملة لمصادر الأسمدة المختلفة من التطبيقات الحتمية للزراعة المستدامة لذا، أقيمت تجربتان حقليتان بمركز البحوث الزراعية بكلية

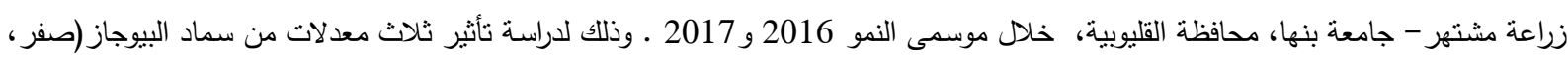

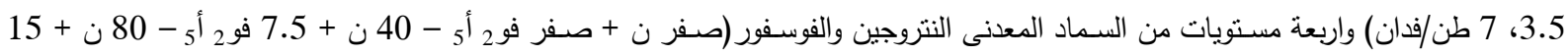

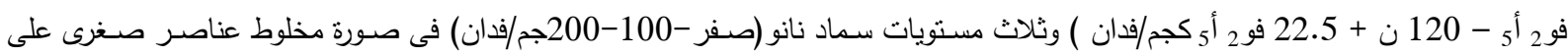

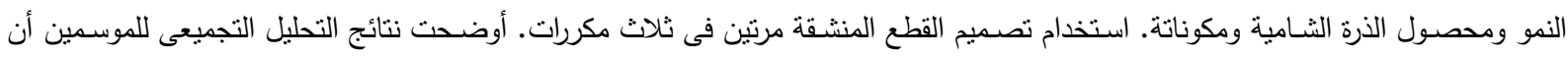

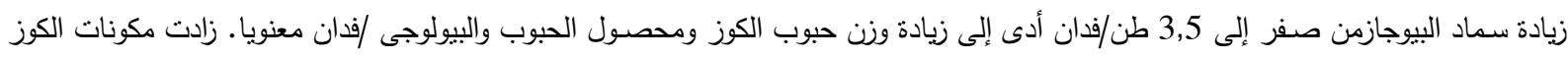

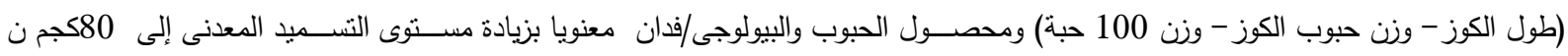

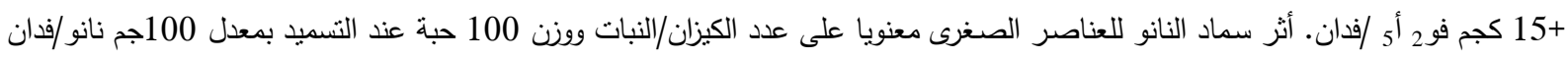

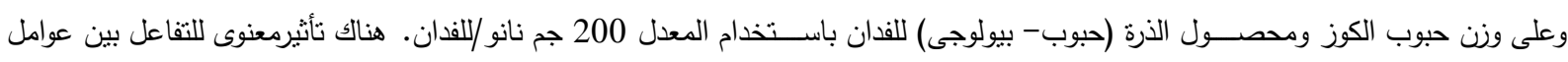

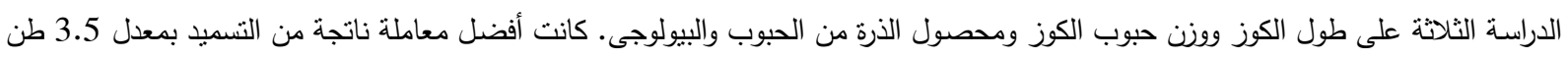

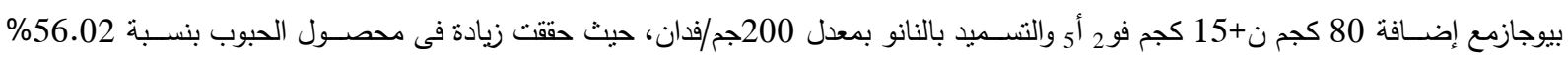

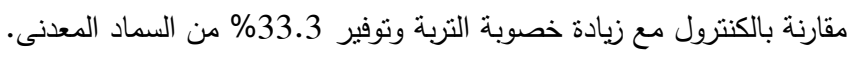

